\title{
Reinvigorating a political ecology of the global agri-food system
}

\section{SÖREN KÖPKE}

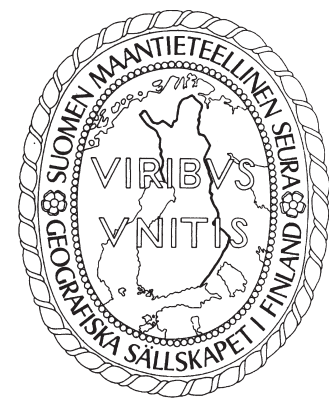

Köpke, S. (2021) Reinvigorating a political ecology of the global agri-food system. Fennia 199(1) 89-103. https://doi.org/10.11143/fennia.99209

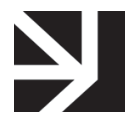

This contribution is a critical review of research on the global agrifood system directly or indirectly identified as political ecology (PE). It shows how food, famine and agricultural production were important topics to early proponents of $\mathrm{PE}$, especially with regards to a critique of neo-Malthusian thought. It then traces further developments in the field and highlights the productive tension between materialist and poststructuralist streams, as well as the influence of actor-network theory. Further on, the paper discusses three neighbouring theories and frameworks with a potential to stimulate current political ecologies of food and agriculture, namely critical agrarian studies, food regime theory and world-ecology. Finally, seven clusters of potential research topics for a political ecology of the global agri-food system are identified. In conclusion, the relevance of PE as a theoretical lens is reiterated and the need for fruitful application of political ecology and related approaches is expressed.

Keywords: political ecology, global agri-food system, world hunger, food studies

Sören Köpke (https://orcid.org/0000-0001-8647-2639), Section of International Agricultural Policy and Environmental Governance, University of Kassel, Steinstr. 19 (Kloster), 37213 Witzenhausen, Germany. E-mail: soeren.koepke@web.de

\section{Introduction}

The global agri-food system appears to be fragile and dysfunctional. It allows one in nine people to go hungry every day (FAO et al. 2019), it contributes greatly to biodiversity loss, soil depletion, water stress, and greenhouse gas emissions (Gladek et al. 2017). While food production and food consumption are tied to the household, underlying power structures and social-ecological relations are not confined to the domain of individuals or families. Food insecurity is always local and householdlevel first and foremost (Misselhorn 2005; Bartfeld \& Wang 2006), yet connected to the agri-food system on higher scales, through national economies, trade, food policies, global environmental change, and a host of other factors. It is a challenge for scholars of development studies, geography, and anthropology to theorize the different factors shaping the current global agri-food system.

Agri-food system is a term derived from insights on the systemic, interconnected and multi-scalar character of food and agriculture; Rogers, Castree and Kitchin $(2013,11)$ define agri-food systems as the "totality of actors involved in the production, distribution and consumption of food, the relations 
between them, and the regulatory apparatus governing these arrangements". Talking about "agrifood systems" suggests looking at the whole of the food value chain by investigating the effects of globalization on local production system, taking into account food policies and political economies of food, and suggests researching interdependencies, for example with ecological processes, political structures, and developments in science and technology.

The question that this review is concerned with is how different approaches of political ecology (PE) describe and analyse the complexity of the global agri-food system. Specifically, it will shed light on the different building blocks of a political ecology of the agri-food system, and scrutinize their respective explanatory powers as well as blind spots. To acknowledge the contribution of political ecology to the understanding of the global agri-food system, the paper continues as follows: it first presents a review of the intellectual origins and theoretical concepts of the approach, then discusses central theoretical strains outside of "political ecology proper" that could provide a stimulus for theoretical advancement within PE, and finally points to a number of key topics that the paper suggests PE research should take on. Global food production is highly contested (Lang \& Heasman 2015). This contribution argues that the political ecology could improve the understanding of power structures permeating the global-agrifood-system, and, vice versa, that increasing focus on the agri-food system would heighten the approach's continued relevance to questions of nature-society relations.

\section{Defining and rooting political ecology as a theory of food systems}

It is a broad approach to questions regarding the politics of natural resource use, and nature-society relations in general. This being said, it branches out into different areas of concern, including gender (feminist political ecology - see Rocheleau et al. 1996) and cities (urban political ecology), and heterogeneous fields of research like biodiversity conservation, land use, mining, water management, forestry, climate adaptation and so on.

Despite the eclecticism, there are a number of shared core features. One is the focus on remote, historic, complex causes as opposed to proximate and reductionist causation; another one is the interest in power (in other words, the political) and its impact on natural resource use and ownership, including an interest in central actors like the state, capital, and subaltern people; a third one is critical thinking about the political character of ideas and knowledge production on "the environment". A fourth general characteristic is an inter- or even trans-disciplinary research strategy, reflected in the methodology used for research (Zimmerer \& Bassett 2003). PE, which originally emerged from geography and anthropology, has become an "interdiscipline" (Kull \& Rangan 2016). These four core qualities are almost all present in works under the political ecology header. Here and there is an overlap with other, neighbouring (and sometimes rivalling) approaches such as environmental justice studies, Science and Technology Studies (STS), social-ecological systems research, environmental humanities, or human-animal studies.

My key argument here is that political ecology, over the last decade, has lost ground in efforts to describe and scrutinize the global agri-food system; in other words, the approach has not made use of its full potential to critically analyse essential issues like persisting malnutrition, trade in agricultural commodities, climate change and farming, rural water politics, land acquisitions, and capitalist modernization of agri-food systems. I am not saying that there is not enough research on these topics, only that political ecologists are often missing a voice in the debate. Curiously, scholars of PE, vocal on food and agriculture in the early years of the research agenda, appear to have now lost interest in some of these topics - leaving us puzzled with the question why this may be so. It is not if there is nothing left to say anymore?

The political ecology research tradition had its point of departure in the 1970s from an interest in peasant agriculture and rural development. Its roots lay in anthropology and, most notably, geography, in a tendency of academic Marxism in the $1970 \mathrm{~s}^{1}$. Among the earliest exponents, many (but not all) were positioned firmly in the theoretical tradition of dialectical historical materialism. Louis Althusser's structural Marxism, dependency theory brought forth by Gunder Frank and others, and Immanuel Wallerstein's world systems theory were highly influential intellectual currents (Bryant \& Bailey 1997, 12-13; Paulson et al. 2003, 207). The genesis of political ecology was therefore very much part of a general zeitgeist. 
Since the late 1960s, there was a decline in modernization-fuelled progress optimism; the constraints to human development imposed by natural resource use and environmental degradation now appeared to be urgent. With a rise in environmental consciousness in developed countries, there began a feverish search for answers to questions posed by famine, desertification, deforestation and dwindling energy reserves ${ }^{2}$. Among these questions, maybe the most crucial, existential is this: why is there hunger and famine? There are many answers to this question. In the conventional view, the root causes of the scourge of famine were made out: scarce food due to droughts, lack of technological development, but mostly: overpopulation in the "Third World" (Ehrlich 1971).

Political ecology took shape as an explanatory framework opposed to these conceived wisdoms, these "apolitical ecologies" (Robbins 2019, 8-21). It insisted that environmental change, as well as hunger and poverty, had a political economy, were permeated by power relations and shaped by historical processes.

\section{Development of a political ecology of food and agriculture}

\section{Against Malthus}

Political ecology first emerged as anti-Malthusianism, and therefore it is necessary to devote a few paragraphs to Malthus and his ideas - ideas which continue their influence until today, if in "zombified" 3 versions (de Waal 2016). Malthus ideas are persistent because they provide a consistent, logically elegant, yet false explanation for hunger. Thomas Robert Malthus (1766-1834) was a British cleric and founding father of political economy; his work (2015[1798]) An Essay on the Principle of Population established his call to fame as a pioneer of political economy. His pessimistic assumption was as follows: the growth in available food would always be less than the growth in human population, thus leading to an inescapable food scarcity crisis. Since "negative checks" - chastity and sexual restraint - were unlikely, only so-called "positive checks" could hold population growth at bay: famine, disease, war. In other words, hunger and misery were inevitable facts.

Malthus has been criticized sharply in development studies, economics and famine history. His theory proved to be empirically problematic and was debunked by history. For instance, Malthus did not account for increase in productivity through technological development.

Supply-side scarcity was long thought to be a cause for hunger crises; this was the so-called "food availability decline" (FAD) hypothesis (Devereux 2009, 26). Sen's (1981) Poverty and Famines elaborated upon an altogether different explanation of famine, the so-called entitlement approach. Entitlements are the base of economic food security and could appear in different forms: income, subsistence production, from heritage or gifts, or from selling one's own property. Accordingly, Sen found lack of entitlements (not lack of food!) to be responsible when parts of the population went hungry. This was a structural explanation to hunger that saw crass socio-economic differences and persistent poverty as root causes of hunger, and therefore resonated well with the interest in power relations pursued by political ecologists (Batterbury \& Fernando 2011[2004], 362). Sen's political economy of famine, combined with a Marxist critique of Malthus, guided PE's perspective on the genesis of hunger ${ }^{4}$.

\section{Political ecology of food crises}

Drought as an agricultural disaster, alongside devastating floods, has driven food crises for centuries, if not millennia (Ó Gráda 2009, 14-18). However, in modern times, there were more factors that together caused famine than just failing rains. Two ground-breaking studies have co-founded the political ecology of drought-famine: Watts' (2013[1983]) Silent Violence and Davis' (2002) Late Victorian Holocausts. The former explores the political economy of northern Nigeria, frequently stricken by famine, and traces it back to colonial history. In a similar manner, but on a grander scale, Davis (2002) investigates the misdemeanour of British colonial rulers in India in the face of the ravaging droughts of the late $19^{\text {th }}$ century. These droughts were most likely brought about by the climatic phenomenon called El Niño Southern Oscillation (ENSO), but the neglect of British rulers played a significant role in escalating the food crises, as Davis meticulously explains. The British imperialists, influenced by 
Malthusian thought (Davis 2002, 32), believed food aid to be an ineffective and even counterproductive way of handling food crises. Davis $(2002,279-310)$ argues that the result was not only a short-term peak in excess mortality from famine among the colonial subjects, but also enduring patterns of underdevelopment. Both Watts and Davis were inspired by materialist accounts of imperial history and highlighted the structural causes, as well as the political economy, of drought-famines.

Apart from drought, there are other immediate factors to low productivity and resulting poverty and food insecurity among peasant farmers. Blaikie (1985) researched structural and social causes of soil erosion and tried to deconstruct the image of peasants as ignorant, poor land managers, pointing towards nested scales of environmental change. Subsequently, Blaikie and Brookfield (1987) addressed the more overarching question of social, political-economic and historic root causes of land degradation. Kull (2004) wrote a critical study of fire use in local shifting cultivation practices in Madagascar. All the authors discussed here are marked by their intention to contribute to a historically informed, materialist social science of food and agriculture.

\section{The constructivist turn}

Most scholars agree that in the 1980s to 1990s, there was a paradigmatic shift that can be described as a waning of Marxian influences, and an increase of poststructuralist thought, associated mainly with the work of Michel Foucault. Foucault's work had garnered considerable intellectual resonance in Western academia by the time of his death in 1984, and continued its triumphal ascendance within critical social science and humanities throughout the 1990s. The French poststructuralist developed his extremely idiosyncratic method in his "archaeology" of ideas and practices, with a main interest in the "power-knowledge" nexus and the notion of "governmentality" (Foucault 2007). Governmentality describes a mode of rule permeating human bodily existence and thus internalizing power through the subject with the means of "technologies of the self".

Foucault was, without a doubt, a highly original and complex intellectual. The different concepts he brought forth have proven to be as adaptable as initially provocative. One of the most prominent applications (or permutations) of the Foucaultian concept of governmentality can be found in Agrawal's (2005, 216-217) Environmentality. In his case study of villagers/subsistence farmers in Kumaon, North India, Agrawal traces how the practice of burning the forest transformed from anticolonial resistance in the 1920s to an undesirable action in the 1990s, when villages actively pursued reforestation instead. In Agrawal's analysis, processes of decentralization had profoundly changed the relations between the spheres of the local and the state, between local-level decision-makers and villagers. Technologies of "intimate government" lead to an internalization of environmental consciousness and direct actions regarded "environment-friendly" (Agrawal 2005, 164-200). Here, the analysis of agrienvironmental processes has shifted from matters of political economy to more subtle questions of discourse, ideology and social control.

In a similar way, Escobar $(1995,1996)$ was among those who exemplified a move away from research on the political economy of peasant production in developing countries, and towards a critique of development as a concept, and the discursive construction of development.

The postmodernist/poststructuralist/constructivist reorientation (Biersack 2006, 22; Peet et al. 2010, 32-33) has diversified the research agenda of political ecology. The question here is whether materialism (derived from Marx) or poststructuralism (inspired by Foucault and his intellectual peers) are two forms of political ecology, as Tetreault (2017) suggests, or merely two phases, as Bryant and Bailey (1997, 12-15) argued earlier. I would suggest that there is a spectrum, not an ontological divide, within a unified yet heterogeneous epistemic community. Self-identified political ecologists are unified by their emphasis on power and inequality within social-ecological interactions; whether the flows of power and inequality are traced through knowledge, language and discourses or through political economies, physical geographies, or environmental histories is a matter of emphasis and method, but not so much of a difference in political outlook. The approach remains fundamentally critical, and hence normative, in its evaluation of received wisdoms.

A third thread, however, might add a new quality in broadening the scope of themes that should be exposed to critical inquiry. Bassett and Peimer (2017) propose a threefold typology of PE research, 
consisting of society/nature dialectics (what I here call "materialist" approaches), the environmentalist constructivist approach (more or less identic with a poststructuralist-influenced approaches), and a third strand, the "co-production of socionature", which can be linked to actor-network theory.

\section{Actor networks}

Actor-network-theory (ANT) was first developed in Science and Technology Studies (STS) by authors like Michel Callon, John Law, and Bruno Latour, who became its most noticed proponent. ANT undermines the foundations of more traditional social sciences by declaring structures and dichotomies non-existent. ANT intends to overcome the object-subject divide (Latour 2005). Human and non-human beings, animate and non-animate objects, together called "actants", form networks of relations and act together as assemblages. This fundamentally non-anthropocentric perspective attributes agency to other beings, or even non-beings, which work together with humans. The farmer works in an assemblage with the hoe, the tractor, the soil and the seed, for instance.

ANT insists that non-human and human "actants" have symmetric relations, and in other words, that we cannot understand anything without acknowledging the networks it is embedded in. From this insight comes a need for a new language to accompany the new sets of concepts. However, the unclear political implications of ANT, mostly associated with its staunch rejection of dualisms, have presented grave irritations to scholars of critical or Marxian political economy (Castree 2002; Fine 2005). Since it refuses to recognize any notions of power structures or inequality, ANT has been accused of catering to neo-liberalism; therefore, that it should be discarded as a theoretical influence to PE (Lave 2015). Other scholars have incorporated its language and theoretical assumptions into political ecology research. It appears that ANT's perspective on symmetry between subjects/objects/ beings/actants has resonated most widely with feminist political ecology (Rocheleau 2015), in particular with Haraway (1991). Among the most original, and perhaps widely read, inquiries into networks and agencies is Tsing's (2015) The Mushroom at the End of the World, an anthropology of food, a fusion of feminist political ecology and ANT, which explores the value chain of the Matsutake mushroom.

The question whether ANT is a diversion from, or a useful addition to more dialectical versions of PE remains unanswered. Yet, more in general, ANT's influence on thinking about social-ecological dynamics remains strong.

\section{Political ecology and its neighbours}

The newer theoretical developments in political ecology admittedly broadened the perspective, but also diverted attention from questions of agricultural production and rural development. As if political ecology had exhausted its theoretical fervour on the topic, it was overtaken. Increasingly other, neighbouring schools of thought produced critical stances on modern food and agriculture. Here, in turn I discuss critical agrarian studies, food regime theory, and world-ecology, three theoretical approaches related to $\mathrm{PE}$, which transcend some aspects of received theory. The nuances of theoretical debates within and between these schools, and their varying degree of engagement and overlap with $\mathrm{PE}$, sometimes appear to be puzzling. All three approaches are marked by attachment to Marxian thought. Yet at a closer look the topical focus is either more narrow than in PE (food regime theory), the ontological position more rigid (world-ecology), or the epistemic community defined mainly by group affiliations and concepts differing from PE (critical agrarian studies).

\section{Critical agrarian studies}

Critical agrarian studies are not a discipline or an approach, but rather a field of interest and an epistemic community. It is a moniker for a decade-long tradition rooted in peasant studies, freshly coined in 2009 with the establishment of the Critical Agrarian Study group in The Hague (AkramLodhi 2018). Critical agrarian studies are centred on a number of key publishing outlets, institutions of higher education, and key authors. The Journal of Peasant Studies, and The Journal of Agrarian Change are the academic journals mostly associated with critical agrarian studies, and the research 
agenda strives at the International Institute of Social Studies (IIS) of the Erasmus University Rotterdam, situated in The Hague.

Among the key actors, one finds Saturnino M. Borras, Jr., who is professor at IIS, Henry Bernstein, who held a chair at the University of London's School of Asian and African Studies (SOAS), and A. Haroon Akram-Lodhi, Wendy Wolfort, Marc Edelman. Notably, there is a dominant focus on the Global South, corresponding with movements on the critical edge of the humanities, such as subaltern studies or post-colonialism (Sajadian 2020, 20).

Methodologically, critical agrarian studies emphasize qualitative social science over large-n studies based on statistical analysis. Topically, the research agenda is somewhat narrow, and focuses on land acquisitions, financialization of food and agriculture, de-peasantization and de-agrarianisation, and finally, environmental degradation and its consequences on peasant agriculture (Akram-Lodhi 2018). The last topic clearly overlaps with the core concern of political ecology: the question of winners and losers in environmental change. However, there are differences in the way both research agendas conceptualize power, social-ecological dialectics, and production of knowledge on "nature"/"the environment". Critical agrarian studies are more overtly linked to Marxian political economy and the pursuit of the "agrarian question" inherited from peasant studies; in contrast to political ecology, which has become considerably heterodox, as mentioned above. PE is less interested in the exact functioning of the modern capitalist world economy, and more invested in researching the workings of capitalism-state alliances on ecosystems and social formations. Hence, political ecology's conceptualization of capital/state actors often appears quite schematic, while other critical social sciences (including critical agrarian studies) are utilized as sources of inspiration and providers of critical tools.

One has to acknowledge that political ecology and critical agrarian studies have not only converging research agendas and theoretical roots, but there are also some authors oscillating between one and the other perspective, or seeking ways to integrate them seamlessly. In particular, critical agrarian studies have popularized and advanced the political economy of the phenomenon called landgrabbing, which had become virulent since 2009: "The emphasis on land, especially in the matters of green grabbing, increasingly blurs an already thin line between critical agrarian studies and political ecology" (Dunlap \& Jakobsen 2020, 52).

Critical agrarian studies and political ecology also share an interest in remote effects and global connections, which are converging in food regime theory as a historical, macro-level mode of explanation of structural change in food production, trade and consumption.

\section{Food regime theory}

Friedmann and McMichael (1989) were the first to introduce food regime theory. It is derived from regulation theory, a Marxist political economy approach of French origin, and has a perspective on the longue durée of change in patterns of food production and consumption, by connecting food regimes to shifting modes of production within capitalist development. According to Friedmann and McMichael, the first global food regime (1870s-1930s) coincided with the emerging hegemony of British colonialism and was characterized by imports of tropical food commodities from the colonies in the Global South to Europe, and provision of grain stables from settler colonies. The second food regime (circa 1950-1970s) began roughly after the Second World War and was marked by large-scale food exports from the US to developing countries in order to stabilize US hegemony in the Cold War context (McMichael 2009, 141). National development programs and particularly adoption of "Green Revolution" technologies were designed to improve food security and dampen social conflicts in many of the post-colonial, newly independent countries.

There are debates on the manifestation of a third food regime (Burch \& Lawrence 2009; McMichael 2013), the "corporate food regime", in which neo-liberal globalization has led to a hegemonic role of oligopolistic corporations on the world market. Accordingly, this food regime is associated with the rise of corporations controlling bottlenecks in the agribusiness value chain (inputs like fertilizers and pesticides; grain trade; food processing; also retail). Friedmann (2005) theorizes the emergent food regime as a corporate-environmental food regime characterized by a "greening" 
of capitalism and a progressive capture of "alternative" niches, created by social movements, through large enterprises.

As mentioned above, food regime theory is a macro-level theory. Its merits can be found in the ability to connect overarching developments within the global agri-food systems to the changing character of world capitalism. However, this grand perspective is not helpful to some of the more micro- or meso-level research question that political ecology seeks to answer.

Tilzey (2018) has undertaken the attempt of integrating food regime theory with political ecology through concepts of food sovereignty and agro-ecology. He focuses on expressions of resistance and counter-hegemony emerging within the historical moments shaped, amongst other factors, by food regimes. Through a dialectic perspective and a critical realist ontology he tries to solve the apparent contradictions between discourse-oriented and materialist strands of PE. This, however, leads him to a rejection of more overtly constructivist approaches he calls "ontologically flat" (Tilzey 2018, 26), like the one we will discuss now, namely world-ecology.

\section{World-ecology}

World-ecology is a theoretically complex post-Marxist intellectual project mainly brought forth by Jason W. Moore, an American historical geographer. World-ecology is influenced by classical Marxism, as well as by World-system theory - an approach mainly associated with Immanuel Wallerstein - and by Latourian actor-network-theory. Moore's main argument, presented in his seminal Capitalism in the Web of Life (Moore 2015), is the rejection of the Cartesian dualism between Nature and Humanity. Over and over again, Moore explains human beings as part of, not in opposition to nature (the web of life, which he calls "oikeos") and hence describes Capitalism as a historical force that has sprung from the web of life, depends on it, and is tightly interwoven with it:

(...) Capitalism becomes not only a producer of environmental changes, but a product of the web of life and involved in a historically and geographically cascading and uneven mosaic of changes (...). (Entitle 2016)

Consequentially, Moore criticizes classical environmentalism, which he sees as charged with Cartesian thought: this environmentalism objectifies nature as it talks about human destruction of the environment, a misconception, as exploitation of "nature" and "fellow humans" are basically the same, intertwined process of accumulation. Moore has therefore engaged in a debate on the agency of nonhuman entities, and taken the sides of those who want to appoint non-human actors a greater role in shaping historical, evolutionary and geopolitical processes (see also Lave 2015; Robbins 2019, 223235). Moore himself believes that world-ecology has the potential to shift political ecology debates into a more decisively "non-Cartesian" direction (Entitle 2016), that is, to dissolve the socially constructed barriers between human/society and nature/resource. As can be imagined, Moore's approach is not always well received, for instance by contemporary Marxists, who accuse him of theoretical vagueness and post-modern fallacies (e.g. Foster \& Clark 2016).

A particular aspect of Moore's theory is of importance to a political ecology of the global agri-food system, namely the concept of "cheap food", elaborated in the book A History of the World in Seven Cheap Things, co-written with Patel (Patel \& Moore 2018; for critique of the work see: Angus 2018; Hornburg 2020). In their chapter on cheap food (Patel \& Moore 2018, 138-160), they sketch the history of the modern food system since Columbian times, stating: "Capitalist agriculture changed the world" (ibid., 140). They claim that the efficiency of modern agriculture in increasing labour productivity and creating agricultural surplus is the fundament of the capitalist mode of production. Urbanized industrial workers need access to cheap food so that capitalists could keep wages low and extract even more surplus value from labour (ibid., 143-144); Patel and Moore see this process repeated in contemporary times with the production of cheap animal protein for consumption (ibid., 155-157). This stance has the merit of embedding agri-food production under capitalist conditions in a wider perspective on global power relations, as well as historicizing the current agrifood system, yet one cannot help but ask how the concept of cheap food is different from the central insights of food regime theory. 
With a nod to historical materialism, the authors propose that every historic mode of production must end: "With climate change, that food system will break in the coming century" (Patel \& Moore 2018, 160). However, one must ask, is this not an ecological reformulation of the Food Availability Decline, a version of neo-Malthusianism and its obsession with scarcity-induced conflicts and disasters? Here, Moore and Patel's world-ecology project might have departed from PE's antiMalthusian consensus.

\section{Emerging issues in the global agri-food system}

If $\mathrm{PE}$ is to regain its cutting edge with critical inquiry of the global agri-food system, then it will have to engage with concrete and urgent empirical questions. Taking real-world problems, not theoretical puzzles at a point of departure offers the potential to dissolve tensions between constructivist and material perspectives. Depending on each topic, the PE toolkit (Robbins 2019, 47) can provide fitting theoretical and methodological instruments for the analysis of complex empirical problems.

A host of research questions springs up from the real-life conditions in the different realms and provinces of food and agriculture. Here, based on my own research, reading, and teaching, I introduce a non-exhaustive list of seven research agendas for PE with continued or growing importance in relation to the global agri-food system, as a starting ground for more detailed or crosscutting inquiries. For each research agenda, I present contemporary contributions, acknowledging that not all of the authors mentioned here would be comfortable to be labelled under "political ecology".

\section{Big food}

One central feature of the global agri-food system is the hegemonic presence of few players (Reardon 2007; Howard 2016), in short: "Big Food". For instance, international trade in agricultural commodities is dependent on five large players: Archer Daniels Midlands, Bunge, Cargill, Louis Dreyfus, and more recently, Cofco of China (Heinrich Böll Foundation et al. 2017, 26). Also, the market in processed food is a multi-billion dollar industry shaped and controlled by transnational corporations (TNC) like Nestlé, Mondelez International, Mars, Coca-Cola, Danone, PepsiCo, Kellogg, Unilever and ABF, who possess immediately recognizable house brands marketed all over the world. Looking at the downstream parts of global value chains, we find massive concentration in food retail. In any given developed country, a few supermarket or megastore chains control the food retail market: Auchan and Carrefour in France, Walmart, Kroger and Costco in the US, Tesco in the UK, Aldi and Rewe in Germany, and so on - oligopoly structures in retail gives the large chains a dramatic leverage on pricing, which is responsible for a price squeeze on producers which extends through global value chains, and ultimately, effects agri-ecological relations in producing regions.

Symbolic commodities such as coffee (Tucker 2008; Jimenez-Soto 2020) and vanilla (Osterhoudt 2017), or monoculture flexcrops like palm oil (Pichler 2015), are subject to price volatilities, boom-andbust cycles, and expansion drives in commodity frontiers that impact people and landscapes. Vandermeer and Perfecto (2013 [1995]), for instance, have done research along these lines, connecting rainforest destruction in Latin America to consumer's love of bananas. Political ecologies of big food corporations and commodity chains might converge with food regime theory and critical agrarian studies by highlighting global interconnections across long distances. For Hall (2015), this focus on high-value export commodities is what ought to be the central focus of a PE of international agri-food systems. However, there is certainly more to the overall theme then this rather narrow, yet important, focus. Again, there is a possibility here to "ground" food regime theory in more localized accounts.

\section{Modernized agricultural production}

The so-called "Green Revolution", a technology-driven transformation in agricultural production, has swept many countries of the Global South since the 1960s. However, it is still underway in regions with the least productive agricultural production systems, hence the talk of "a new Green Revolution" in Sub-Saharan Africa (for a critique, see Holt-Giménez \& Altieri 2013; Ignatova 2017). Shiva, the 
Indian scholar-activist and a political ecologist in everything but in name, is the most prolific and vocal critic of the "Green Revolution" and agri-business expansion in India and the Global South (Shiva 2000, 2008). The socio-technological and environmental disruptions associated with modernized, and constantly modernizing, agricultural production systems are fruitful (but often also frightening) material for case studies. For instance, the study colleagues and I have conducted on Sri Lanka's dry zone (Köpke et al. 2019) was an attempt to examine the social-ecological problems brought forth by those "modern" agricultural production systems under the vulnerable conditions of peasant paddy farming. Bezner Kerr, with her collaborators, has published instructive case work on agricultural inputs in Malawi and Ghana (Bezner Kerr 2013; Nyantak-Frimpong \& Bezner Kerr 2015). Given the profound and often very complex transformations associated with the changes in agricultural production systems in many countries, this topic is certainly apt to produce numerous empirical cases for years to come.

\section{Hunger, nutrition, health and obesity}

A pressing question remains what PE has to say about the continuing hunger crisis. As a normative approach, the topic of hunger and malnutrition is surprisingly out of focus in modern PE.

Famine studies appear to come to the conclusion that "modern" famines, that is those that have been experienced within intensifying waves of globalisation since the $19^{\text {th }}$ century, are primarily political of origin and often connected to armed conflict and genocidal activities of state actors. In the words of de Waal $(2018,6)$, people have not been starving from lack of food, they are actively starved by powerful people. Although most calamitous famines have occurred before 1980 (de Waal 2018, 5), the intimate connection between armed conflict and hunger persists. Around two third of people experiencing acute hunger live under conditions of armed conflict; Yemen, the Democratic Republic of Kongo, and Afghanistan are the three countries with the highest rates of conflict-related food insecurity (FAO \& WFP 2019; FSIN 2019). Another "hot topic" is the nexus between the climate crisis and food insecurity. While climate change has undeniable negative impacts on food systems, there is amble room to challenge received wisdom on interconnections between the climate crisis, food insecurity, and social conflict (Dalby 2009; Taylor 2015). This space for critical inquiry also extends to questions related to climate mobility and food security (McMichael 2014). A political ecology of hunger must put up resistance against attempts to naturalize hunger and famine and continue to point to the geopolitical and political-economic roots of contemporary hunger crises, and to counter the reemergence of neo-Malthusian narratives incorporating climate change as a new factor.

At the same time, it is important to broaden the perspective, addressing chronic malnutrition throughout the world. Many developing countries are in the process of nutrition transition (Qaim 2017); a global crisis of malnutrition here unrolls in the form of obesity, a condition with severe health implications driven by expanding retail chains, and the marketing of cheap (processed) food rich in saturated fats, sugar and salt contents.

\section{Meat and alternatives}

Part of the transformation in food practice is the increase of meat intake in many parts of the world. Most of the time the meat industry is taken as a given, as a hyper-efficient way of providing affordable meat to consumers. However, during the Covid-19 pandemic, slaughterhouses and meat packaging factories were suddenly in focus of public interest, working conditions obviously so bad that SARSCoV2 was spreading fast in this environment. A political ecology of meat looks at power dynamics and environmental consequences throughout the value chain; Neo and Emel (2017)'s take on the "geographies of meat" might be a point of departure for such an inquiry. There are also possibilities to draw connections to a political ecology of the post-human (Margulies \& Bersaglio 2018), as influenced by ANT and related approaches. Animal rights activists like PETA and celebrities like ExBeatle Paul McCartney advocate for vegetarian lifestyles and "compassionate" consumption. Ethical questions and consumer choices have altered the market in peculiar ways. Finally, lab-grown (in vitro) meat emerges as a field of inquiry for critical political ecology (Mouat et al. 2019). 


\section{Green consumerism and claims to sustainability}

Vegetarianism and veganism have become accepted lifestyle choices of ethical consumption in developed countries, but they are just a part of a larger obsession with "green", sustainable, and healthy food. Lifestyle food commodities are subject to boom cycles like any other commodity - with serious repercussions for subsistence in developing countries. Quinoa, an Andean crop that has been promoted as "superfood" to consumers in the West, is a case in point (Kerssen 2015; Andrews 2017). Almonds are another popular "superfood" (Reisman 2020), one that been debated for its water footprint in the face of the Californian megadrought (Gonzalez 2015).

While organic food, superfood and health food all make a claim to more eco-friendly and bodyconscious consumer decisions, they also represent multi-billion dollar economies. Especially the market in organic foods has grown considerably over the last decades, but has also undergone large structural changes. The boom- and bust cycles of organic and superfood, contrasted with the "health fads" of the global urban middle classes, are prone to highlight the remote effects of allegedly "sustainable" food trends.

\section{Fish, fisheries and seafood}

The extraction of animal protein (fish, crustaceans, molluscs) from the world's waters, be it oceans, lakes, streams or aquaculture, is an important and under-researched topic. Fisheries and fisherfolk are side-lined within PE research, despite the fact that seafood and fish protein is an essential foodstuff for many, primarily marginalized communities the world over. There are some excellent contributions tackling salmon in aquacultures (Barton \& Fløysand 2010) and in the wild (Swanson 2015). Salmon owes its prominence, again, to its role as a symbolic and valuable commodity.

The Journal of Political Ecology published a virtual special issue on the "Blue Economy in Africa" in 2019 (Childs \& Hicks 2019) that dealt, among other sectors, with fishing, but it was focused on extractivist activities like deep sea mining.

Fisheries have an explicitly geopolitical dimension: in the Indian Ocean piracy crisis on the Somalian coast, driven by a decline in fishing as a livelihood strategy; and a number of other interstate disputes over fishing rights, with the historic "Cod Wars" between the UK and Iceland (Steinsson 2017) as a prime example. The practice of industrial fishing (Yagishita 2018) deserved to be understood from a political ecology angle rather than more positivist game-theoretic analysis (for an example of the latter, see Munro 2009; for a critique, Mansfield 2010).

\section{Beyond the regional bias: Addressing geographical blind spot}

Finally, if political ecology as a theoretical approach strives to expand its impact, it should also extend its regional focus. While the Western hemisphere (and Latin America in particular), larger parts of SubSaharan Africa, parts of South and South East Asia are amply covered in research on agri-food systems, there remain many blank spaces on a PE world map, despite the claims to "global political ecology" (Peet et al. 2010). China, for instance, is sparsely covered (Yeh 2015); not to mention Central Asia, which does not seem to draw much interest. There certainly should be PE research on China's Belt and Road Initiative (BRI), the gigantic infrastructure and trade initiative, yet there is hardly anything (Matthias Schmidt, personal communication, March 1, 2019). Certainly, the BRI will have consequences on agri-food systems in the participating countries, given China's outstanding role as both a food consuming and food producing country (for a starting point, see McMichael 2020).

A climatic zone that has not figured prominently in PE research is comprised of the Nordic regions ${ }^{5}$ - Scandinavia, Greenland, the Siberian North, Alaska or the north of Canada. These vast regions have potential for research agendas on indigenous livelihoods and traditional ecological knowledge (TEK), studying, for example, indigenous food production and food knowledge (of the Samí or the Inuit, to name just two), pastoralism and fishing, and conflicts between rural livelihood strategies and resource extractivism. Although some inroads have been made into the new terrain of Nordic political ecology (Heikkinen \& Robbins 2006; Benjaminsen \& Robbins 2015), there are highly relevant 
and emerging research questions to be found centred on the Nordic regions, also for food and agriculture, especially in the context of climate change.

\section{Conclusion}

In today's political ecology scholarship, there is a marked presence of four very large issues: extractivism, energy production, water, and conservation. This becomes clear when looking at recent conferences, journals and academic books. Political ecologists undertake excellent research in all four fields, and they merit high relevance. Yet it is not comprehensible why the equally important issue of food and agricultural production systems should take a backseat, or should be left to other schools and approaches. Although, as argued elsewhere (Köpke 2018), there may be an intimate connection between food, water, extractivism and energy production, I hope to have shown that a political ecology of the agri-food system should carry enough weight in its own right to comprise a relevant research agenda.

\section{Notes}

${ }^{1}$ Although he is not a Marxist, James C. Scott has been a constant influence on PE from the early days on (Robbins 2019, 59-60). Scott has consistently applied "academic" anarchism as a critical lens to peasant studies (Scott 1998, 2009, 2012). Hence, the study of the political economies of peasants, smallscale agricultural production, and rural unrest has a decidedly anti-authoritarian streak, and the domain of peasant life appears as perpetually in conflict with representatives of the state and capital alike. Concepts like "moral economy" and "everyday resistance" retain their importance to PE approaches.

2 The Biafran famine (1967-1970), the Sahel drought (1968-1972) and the early 1970s Ethiopian famine, among others, alerted many people in developed countries of the need for humanitarian food relief, and helped shaping ideas of "Third World" disasters. For instance, Oxfam was founded in response to the Biafran famine (O'Sullivan 2014). The UN Conference on the Human Environment in Stockholm, Sweden in 1972 was highly influential in establishing environmental problems on the agenda of international institutions. The 1972 Club of Rome report The Limits to Growth (Meadows \& Club of Rome 1972) ushered in the age of scarcity, as resource abundance appeared to be a feature of the past. The oil price crisis, albeit triggered by Middle East geopolitics in the context of the 1973 Yom Kippur War, lend some credibility to these notions (Dalby 2009, 14).

${ }^{3}$ Kallis (2019) challenges the original Malthusian thought on its own terrain, questioning Malthus' inner logic and motivations to the text. While Kallis' book Limits is a major intellectual achievement, it is rather connected to the political philosophy underpinning the degrowth movement than a text of political ecology. What is more, it does not apply itself overtly to questions of food production and consumption, as it aims for a much broader argument on the limits to growth and the emancipatory potential of self-limiting.

${ }^{4}$ Woo-Cummings (2002) in her essay "The political ecology of famine" is highly critical of Sen, but her definition of political ecology is unrelated to what this article, and the overall science community, understands as political ecology by now.

${ }^{5}$ I owe gratitude to my students in "Critical Perspectives on the Global Food System", summer term 2018 , for pointing me towards this.

\section{Acknowledgements}

This article has a heavy debt to Andreas Thiel, who let me teach the module "Critical Perspectives on the Global Food System" in summer term 2018, a master level course of students of Organic Agricultural Sciences at the University of Kassel. Through teaching the course, I was able to sharpen my understanding of some key issues, and I was likewise exposed to a number of new ideas and theoretical approaches. The lively debates with my students made this process enjoyable and pointed me towards my own blind spots. Ariane Götz has critically read a draft of the paper and 
provided extremely helpful comments. I am also very grateful to the two anonymous reviewers and the chief editor of Fennia for their great support in improving this paper.

\section{References}

Agrawal, A. (2005) Environmentality. Technologies of Government and the Making of Subjects. Duke University Press, Durham and London.

Akram-Lodhi, H. A. (2018) What is critical agrarian studies? Review of African Political Economy blog 28.3.2018 <http://roape.net/2018/03/28/what-is-critical-agrarian-studies/>. 15.6.2020.

Andrews, D. (2017) Race, status, and biodiversity; the social climbing of quinoa. Culture, Agriculture, Food and Environment 39(1) 15-24. https://doi.org/10.1111/cuag.12084

Angus, I. (2018) Illusions of word-ecology. International Socialism 157. <https://isj.org.uk/illusions-ofworld-ecology/>. 30.6.2020.

Bartfeld, J. \& Wang, L. (2006) Local-level predictors of household food insecurity. Institute for Research on Poverty Discussion Paper 1317-06. https://doi.org/10.2139/ssrn.925245

Barton, J. R. \& Fløysand, A. (2010) The political ecology of Chilean salmon aquaculture, 1982-2010: a trajectory from economic development to global sustainability. Global Environmental Change 20 739-752. https://doi.org/10.1016/j.gloenvcha.2010.04.001

Bassett, T. J. \& Peimer, A. W. (2015) Political ecological perspectives on socioecological relations. Natures Sciences Sociétés 23(2) 157-165. https://doi.org/10.1051/nss/2015029

Batterbury, S. P.J \& Fernando, J. L. (2011[2004]) Amartya Sen. In Hubbard, P., Kitchin, R. \& Valentine. G. (eds.) Key Thinkers on Space and Place, 359-366. Sage, London.

Benjaminsen, T. A. \& Robbins, P. (2015) Nordic political ecologies. Norsk Geografisk Tidsskrift - Norwegian Journal of Geography 69(4) 191-196. https://doi.org/10.1080/00291951.2015.1059879

Bezner Kerr, R. (2013) Seed struggles and food sovereignty in northern Malawi. The Journal of Peasant Studies 40(5) 867-897. https://doi.org/10.1080/03066150.2013.848428

Biersack, A. (2006) Reimaging political ecology: culture/power/history/nature. In Biersack, A. \& Greenberg, J. B. (eds.) Reimagining Political Ecology, 3-40. Duke University Press, Durham and London. https://doi.org/10.1215/9780822388142-001

Blaikie, P. (1985) The Political Economy of Soil Erosion in Developing Countries. Longman, Harlow.

Blaikie, P. \& Brookfield, H. (1987) Land Degradation and Society. Methuen, London.

Bryant, R. L. \& Bailey, S. (1997) Third World Political Ecology. Routledge, London and New York.

Burch, D. \& Lawrence, G. (2009) Towards a third food regime: behind the transformation. Agriculture \& Human Values 26 267-279. https://doi.org/10.1007/s10460-009-9219-4

Castree, N. (2002) False antitheses? Marxism, nature and actor-networks. Antipode 34(1) 111-146. https://doi.org/10.1111/1467-8330.00228

Childs, J. \& Hicks, C. C. (2019) Securing the blue: political ecologies of the blue economy in Africa. Journal of Political Ecology 26(1). https://doi.org/10.2458/v26i1.23162

Dalby, S. (2009) Security and Environmental Change. Polity, Cambridge.

Davis, M. (2002) Late Victorian Holocausts. El Niño Famines and the Making of the Third World. Verso, London.

Devereux, S. (2009) Why does famine persist in Africa? Food Security 1 25-35. https://doi.org/10.1007/s12571-008-0005-8

Dunlap, A. \& Jakobsen, J. (2020) The Violent Technologies of Extraction. Political Ecology, Critical Agrarian Studies and the Capitalist Worldeater. Palgrave MacMillan, London. https://doi.org/10.1007/978-3-030-26852-7

Ehrlich, P. (1971) The Population Bomb. The Pan/Ballantine, New York.

Escobar, A. (1995) Encountering Development: The Making and Unmaking of the Third World. Princeton University Press, Princeton.

Escobar, A. (1996) Constructing nature: elements for a poststructural political ecology. In Peet, R. \& Watts, M. (eds.) Liberation Ecologies: Environment, Development, Social Movements, 46-68. Routledge, London.

Entitle (2016) Jason W. Moore: political ecology or world-ecology? Video interview. Entitle blog Youtube channel 5.1.2016 <https://www.youtube.com/watch?v=-fwaw51S9gs >. 23.1.2021.

FAO, IFAD, UNICEF, WFP \& WHO (2019) The state of food security and nutrition in the world 2019. Safeguarding against economic slowdowns and downturns. FAO, Rome.

FAO \& WFP (2019) Monitoring food security in countries with conflict situations. <http://www.fao.org/3/ ca3113en/CA3113EN.pdf>. 5.7.2020.

Fine, B. (2005) From actor-network theory to political economy. Capitalism Nature Socialism 16(4) 91-108. https://doi.org/10.1080/10455750500376057 
Foster, J. B. \& Clark, B. (2016) Marx's ecology and the left. Monthly Review 68(2) 1-25. https://doi.org/10.14452/MR-068-02-2016-06 1

Foucault, M. (2007) Security, Territory, Population. Lectures at the Collège de France, 1977-78. Translated by G. Burchell. Palgrave Macmillan, London.

Friedmann, H. (2005) From colonialism to green capitalism: social movements and emergence of food regimes. In Buttel, F. H. \& McMichael, P. (eds.) New Directions in the Sociology of Global Development (Research in Rural Sociology and Development, Vol. 11), 227-264. Emerald Group Publishing, Bingley. https://doi.org/10.1016/S1057-1922(05)11009-9

Friedmann, H. \& McMichael, P. (1989) Agriculture and the state system: the rise and fall of national agricultures, 1870 to the present. Sociologia Ruralis 29(2) 93-117. https://doi.org/10.1111/j.1467-9523.1989.tb00360.x

FSIN (2019) Global report on food crises. Report. Food Security Information Network, WFP, FAO and IFPRI.

Gladek, E., Fraser, M., Roemers, G., Sabag Muñoz, O., Kennedy, E. \& Hirsch, P. (2017) The global food system: an analysis. Report. Metabolic and WWF Netherlands, Amsterdam.

Gonzalez, R. (2015) How almonds became a scapegoat for California's megadrought. NPR 16.4.2015 <https://www.npr.org/sections/thesalt/2015/04/16/399958203/how-almonds-became-a-scapegoat-forcalifornias-drought>. 3.7.2020.

Hall, D. (2015) The political ecology of international agri-food systems. In Perreault, T., Bridge, G. \& McCarty, J. (eds.) The Routledge Handbook of Political Ecology, 406-417. Routledge, London and New York.

Haraway, D. (1991) Simians, Cyborgs, and Women. The Reinvention of Nature. Routledge, New York.

Heikkinen, H. \& Robbins, P. (2006) New applications of political ecology for the Nordic context. Nordia Geographical Publications 35(2) 3-8. <https://nordia.journal.fi/article/view/76189>.

Heinrich Böll Foundation, Rosa Luxemburg Foundation \& FOEE (2017) Agrifood Atlas. English translation. Heinrich Böll Foundation, Rosa Luxemburg Foundation and Friends of the Earth Europe, Berlin and Brussels.

Holt-Giménez, E. \& Altieri, M. A. (2013) Agroecology, food sovereignty, and the new green revolution. Agroecology and Sustainable Food Systems 37(1) 90-102. https://doi.org/10.1080/10440046.2012.716388

Hornburg, A. (2020) Dialectical confusion: on Jason Moore's posthumanist Marxism. Historical materialism blog 25.6.2020 <http://www.historicalmaterialism.org/blog/dialectical-confusion-jasonmoores-posthumanist-marxism>. 23.1.2021.

Howard, P. H. (2016) Concentration and Power in the Food System: Who Controls What We Eat? Bloomsbury, London and New York. https://doi.org/10.5040/9781474264365

Ignatova, J. A. (2017) The 'philanthropic' gene: biocapital and the new green revolution in Africa. Third World Quarterly 38(10) 2258-2275. https://doi.org/10.1080/01436597.2017.1322463

Jimenez-Soto, E. (2020) The political ecology of shaded coffee plantations: conservation narratives and the everyday-lived-experience of farmworkers. The Journal of Peasant Studies [online Mar 12 2020] https://doi.org/10.1080/03066150.2020.1713109

Kallis, G. (2019) Limits. Why Malthus was Wrong and Why Environmentalists Should Care. Stanford University Press, Stanford, CA. https://doi.org/10.1515/9781503611566

Kerssen, T. M. (2015) Food sovereignty and the quinoa boom: challenges to sustainable repeasantisation in the souther Altiplano of Bolivia. Third World Quarterly 36(3) 489-507. https://doi.org/10.1080/01436597.2015.1002992

Kull, C. (2004) Isle of Fire. The Political Ecology of Landscape Burning in Madagascar. The University of Chicago Press, Chicago and London.

Kull, C. A. \& Rangan, H. (2016) Political ecology and resilience: competing interdisciplinarities? In Hubert, B. \& Mathieu, N. (eds.) Interdisciplinarités Entre Natures et Sociétés, 71-87. PIE Peter Lang, Brussels.

Köpke, S. (2018) New pieces to the puzzle: the food-water-energy-mining nexus in environmental conflicts. Resources and Conflicts blog 20.3.2018 < http://resources-and-conflict.org/2018/03/foodwater-energy-mining-nexus/>. 23.1.2021.

Köpke, S., Withanachchi, S. S., Pathiranage, R., Withanachchi, C. R. \& Ploeger, A. (2019) Social-ecological dynamics in irrigated agriculture in dry zone Sri Lanka: a political ecology. Sustainable Water Resource Management 5 629-637. https://doi.org/10.1007/s40899-018-0220-1

Lang T. \& Heasman, M. (2015) Food Wars. $2^{\text {nd }}$ ed. Routledge, Oxon and New York.

Latour, B. (2005) Reassembling the Social. An Introduction to Actor-Network-Theory. Oxford University Press, Oxford and New York.

Lave, R. (2015) Reassembling the structural: political ecology and Actor-Network Theory. In Perreault, T., Bridge, G. \& McCarty, J. (eds.) The Routledge Handbook of Political Ecology, 213-223. Routledge, London and New York. 
Malthus, T. R. (2015 [1798]) An Essay on the Principle of Population and Other Writings. Penguin, London.

Mansfield, B. (2010) "Modern" industrial fisheries and the crisis of overfishing. In Peet, R., Robbins, P. \& Watts, M. (eds.) Global Political Ecology, 84-99. Routledge, London and New York.

Margulies, J. D. \& Bersaglio, B. (2018) Furthering post-human political ecologies, Geoforum 94 103-106. https://doi.org/10.1016/i.geoforum.2018.03.017

McMichael, C. (2014) Climate change and migration: food insecurity as a driver and outcome of climate change-related migration. In Malik, A., Grohmann, E. \& Akhtar, R. (eds.) Environmental Deterioration and Human Health, 291-313. Springer, Dordrecht. https://doi.org/10.1007/978-94-007-7890-0 12

McMichael, P. (2009) A food regime genealogy. The Journal of Peasant Studies 36(1) 139-169. https://doi.org/10.1080/03066150902820354

McMichael, P. (2013) Food Regimes and Agrarian Questions. Fernwood Publishing, Halfiax \& Winnipeg. https://doi.org/10.3362/9781780448794.000

McMichael, P. (2020) Does China's 'going out' strategy prefigure a new food regime? The Journal of Peasant Studies 47(1) 116-154. https://doi.org/10.1080/03066150.2019.1693368

Meadows, D. H. \& Club of Rome (1972) The Limits to Growth: A Report for the Club of Rome's Project on the Predicament of Mankind. Universe Books, New York. https://doi.org/10.1349/ddlp.1

Misselhorn, A. A. (2005) What drives food insecurity in southern Africa? A meta-analysis of household economy studies. Global Environmental Change 15(1) 33-43. https://doi.org/10.1016/j.gloenvcha.2004.11.003

Moore, J. W. (2015) Capitalism in the Web of Life: Ecology and the Accumulation of Capital. Verso, London.

Mouat, M. J., Prince, R. \& Roche, M. M. (2019) Making value out of ethics: the emerging economic geography of lab-grown meat and other animal-free food products. Economic Geography 95(2) 136-158. https://doi.org/10.1080/00130095.2018.1508994

Munro, G. (2009) Game theory and the development of resource management policy: the case of international fisheries. Environment and Development Economics 14(1) 7-27. https://doi.org/10.1017/S1355770x08004671

Neo, H. \& Emel, J. (2017) The Geographies of Meat. Routledge, London. https://doi.org/10.4324/9781315584386

Nyantakyi-Frimpong, H. \& Bezner Kerr, R. (2015) A political ecology of high-input agriculture in northern Ghana. African Geographical Review 34(1) 13-35. https://doi.org/10.1080/19376812.2014.929971

Ó Gráda, C. (2009) Famine. A Short History. Princeton University Press, Princeton.

O'Sullivan, K. (2014) Humanitarian encounters: Biafra, NGOs and imaginings of the Third World in Britain and Ireland, 1967-70. Journal of Genocide Research 16(2-3) 299-315. https://doi.org/10.1080/14623528.2014.936706

Osterhoudt, S. (2017) Vanilla Landscapes: Meaning, Memory, and the Cultivation of Place in Madagascar. NYBG Press, Bronx, NY.

Patel, R. \& Moore, J. W. (2018) A History of the World in Seven Cheap Things. Verso, London and New York. https://doi.org/10.1525/9780520966376

Paulson, S., Gezon, L. L. \& Watts, M. (2003) Locating the political in political ecology: an introduction. Human Organization 62(3) 205-217. https://doi.org/10.17730/humo.62.3.e5xcjnd6y8v09n6b

Peet, R., Robbins, P. \& Watts, M. (2010) Global nature. In Peet, R., Robbins, P. \& Watts, M. (eds.) Global Political Ecology, 1-47. Routledge, London and New York. https://doi.org/10.4324/9780203842249

Pichler, M. (2015) Legal dispossession: state strategies and selectivities in the expansion of Indonesian palm oil and agrofuel production. Development and Change 46(3) 508-533. https://doi.org/10.1111/dech.12162

Qaim, M. (2017) Globalisation of agrifood systems and sustainable nutrition. Proceedings of the Nutrition Society 76(2017) 12-21. https://doi.org/10.1017/S0029665116000598

Reardon, T. (2007) Global food industry consolidation and rural agroindustrialization in developing economies. In Haggblade, S., Hazell, P. B. R. \& Reardon, T. (eds.) Transforming the Rural Nonfarm Economy: Opportunities and Threats in the Developing World, 199-215. Johns Hopkins University Press, Baltimore.

Reisman, E. (2020) Superfood as spatial fix: the ascent of the almond. Agriculture and Human Values 37 337-351. https://doi.org/10.1007/s10460-019-09993-4

Robbins, P. (2019) Political Ecology. A Critical Introduction. $3^{\text {rd }}$ ed. Wiley-Blackwell, Malden, MA and Oxford.

Rocheleau, D. (2015) Roots, rhizomes, networks and territories: reimagining pattern and power in political ecologies. In Bryant, R. (ed.) The International Handbook of Political Ecology, 70-89. Edward Elgar, Cheltenham and Northampton, MA. https://doi.org/10.4337/9780857936172.00013

Rocheleau, D., Thomas-Slayter, B. \& Wangari, E. (eds.) (1996) Feminist Political Ecology: Global Issues and Local Experience. Routledge, London. 
Rogers, A., Castree, N. \& Kitchin, R. (eds.) (2013) The Oxford Dictionary of Human Geography. Oxford University Press, Oxford. https://doi.org/10.1093/acref/9780199599868.001.0001

Sajadian, C. (2020) Critical agrarian studies. In Kobayashi, A. (ed.) The Encyclopedia of Human Geography, Second edition, Vol. 3, 17-24. Elsevier, Amsterdam. https://doi.org/10.1016/B978-0-08-102295-5.10456-1

Scapegoat (2015) The political economy of soil. Interview with Piers Blaikie. Scapegoat Journal 8 144-149.

Scott, J. C. (1998) Seeing Like a State: How Certain Schemes to Improve the Human Condition Have Failed. Yale University Press, New Haven.

Scott, J. C. (2009) The Art of Not Being Governed: An Anarchist History of Upland Southeast Asia. Yale University Press, New Haven.

Scott, J. C. (2012) Two Cheers for Anarchism: Six Easy Pieces on Autonomy, Dignity, and Meaningful Work and Play. Princeton University Press, Princeton. https://doi.org/10.1515/9781400844623

Sen, A. (1981) Poverty and Famines. An Essay on Entitlement. Oxford University Press, Oxford.

Shiva, V. (2000) Stolen Harvest: The Hijacking of the Global Food Supply. South End Press, Cambridge, MA.

Shiva, V. (2008) Soil not Oil. Climate Change, Peak Oil and Food Insecurity. Zed Books, London.

Steinsson, S. (2017) Do liberal ties pacify? A study of the Cod Wars. Cooperation and Conflict 53(3) 339-355. https://doi.org/10.1177/0010836717712293

Swanson, H. A. (2015) Shadow ecologies of conservation: co-production of salmon landscapes in Hokkaido, Japan, and southern Chile. Geoforum 61 101-110. https://doi.org/10.1016/j.geoforum.2015.02.018

Taylor, M. (2015) The Political Ecology of Climate Change Adaptation: Livelihoods, Agrarian Change and the Conflicts of Development. Routledge and Earthscan, London. https://doi.org/10.4324/9780203762486

Tetreault, D. (2017) Three forms of political ecology. Ethics and the Environment 22(2) 1. https://doi.org/10.2979/ethicsenviro.22.2.01

Tilzey, M. (2018) Political Ecology, Food Regimes, and Food Sovereignty: Crisis, Resistance, Resilience. Palgrave MacMillan, London. https://doi.org/10.1007/978-3-319-64556-8

Tsing, A. L. (2015) The Mushroom at the End of the World. Princeton University Press, Princeton.

Tucker, C. M. (2008) Changing Forests: Collective Action, Common Property, and Coffee in Honduras. Springer, Cham.

Vandermeer, J. \& Perfecto, I. (2013[1995]) Breakfast of Biodiversity. The Political Ecology of Rain Forest Destruction. Food First, Oakland, CA.

de Waal, A. (2016) Malthus's zombie: why are we still scared by stories about scarcity causing atrocities? World Peace Foundation blog 3.2.2016 <https://sites.tufts.edu/reinventingpeace/2016/02/03/ malthuss-zombie-why-are-we-still-scared-by-stories-about-scarcity-causing-atrocities/> 17.6.2020.

de Waal, A. (2018) Mass Starvation. The History and Future of Famine. Polity, Cambridge.

Watts, M. (2013[1983]) Silent Violence. Food, Famine, and Peasantry in Northern Nigeria. University of Georgia Press, Athens and London.

Woo-Cummings, M. (2002) The political ecology of famine: the North Korean catastrophe and its lessons. ADB Institute Research Paper Series 31.

Yagishita, Y. (2018) No more tuna for Japan's sushi. Le Monde diplomatique February $2018<$ https:// mondediplo.com/2018/02/13fishing-japan>. 1.7.2020.

Yeh, E. T. (2015) Political ecology in and of China. In Bryant, R. (ed.) The International Handbook of Political Ecology, 619-632. Edward Elgar, Cheltenham and Northampton, MA. https://doi.org/10.4337/9780857936172.00055

Zimmerer, K. S. \& Bassett, T. J. (eds.) (2003) Political Ecology. An Integrative Approach to Geography and Environment-Development Studies. The Guilford Press, New York and London. 